\title{
An Exploration of Social Entrepreneurship in the Entrepreneurship Era
}

\author{
Mohammad Reza Noruzi \\ Executive Master Business Administration, EMBA \\ Islamic Azad University, Kaleibar, Iran \\ Faculty of Humanity Sciences, Department of Management and Accounting \\ Young Researchers Club Member, IAU Bonab, Iran \\ Tel: 98-426-422-4915 E-mail:mr.noruzi.pnu@gmail.com
}

Jonathan H. Westover

Assistant Professor of Business

Utah Valley University

800 W. University Parkway, MS-119

Orem, UT 84058-5999, USA

Tel: 801-863-8215Ｅ-mail: jonathan.westover@uvu.edu

\author{
Gholam Reza Rahimi \\ Public Management, $\mathrm{PhD}$ \\ Islamic Azad University, Kaleibar, Iran
}

Faculty of Humanity Sciences, Department of Management and Accounting

Tel: 98-426-422-4915

\begin{abstract}
Entrepreneurship has been the engine propelling much of the growth of the business sector as well as a driving force behind the rapid expansion of the social sector. Additionally, the award of the Nobel Peace Prize in 2006 to Mohammad Yunus for founding the Grameen Bank thrust social entrepreneurship into the global spotlight. The Grameen Bank is the world's largest micro-finance organization; it is a profitable business that has helped thousands of people, mostly women, out of poverty. Social entrepreneurship, the simultaneous pursuit of economic, social, and environmental goals by enterprising ventures, has gradually found a place on the world's stage as a human response to social and environmental problems (Haugh, 2007). This paper aims to review and study the recent developments in social entrepreneurship as an important phenomenon in today's entrepreneurship era.
\end{abstract}

Keywords: Entrepreneurship, Social entrepreneurship, Social entrepreneurship training

\section{Introduction}

The concept of entrepreneurship, long hallowed in the context of business ventures, has been increasingly applied to the context of social problem solving (e.g., Dees, 1998; Emerson \& Twerksy, 1996; Thake \& Zadek, 1997). The challenges of finding effective and sustainable solutions to many social problems are substantial, and solutions may require many of the ingredients associated with successful business innovation of the constellation of problems associated with long-term poverty; such problems often demand fundamental transformations in political, economic, and social systems (Alvord et al,2004).

Some research in the development literature has assessed characteristics common to large-scale, successful poverty alleviation initiatives (e.g., Krishna, Uphoff, \& Esman, 1997; Tendlar, 1989). Some investigators have focused on the organizational and institutional characteristics of effective development agencies (e.g., Brown \& Covey, 1987; Korten, 1980; Paul, 1982), and others have looked at the characteristics of successful social 
movements (e.g., Gamson, 1975; McAdam, McCarthy, \& Zald, 1996; Tarrow, 1998: Alvord et al, 2004).

This paper presents a study on entrepreneurship broadly first, then social entrepreneurship specifically, and highlights the behavioral traits possessed by entrepreneurs. First, we introduce the concept of entrepreneurship and then social entrepreneurship, while providing a brief introduction to social entrepreneurs and their activities. Finally, we present an analysis of the traits and major standards of entrepreneurship education that a social entrepreneur is expected to possess in learning the social entrepreneurship process.

\section{Entrepreneurship}

Debate surrounds what entrepreneurship constitutes as a field of study. Enterprise scholars have traditionally focused on the profiles of entrepreneurs and what the entrepreneur does (Gartner, 1989), as well as the performance of individual entrepreneurs and firms. However, Venkataraman (1997) suggested that the field of entrepreneurship research should seek "... to understand how opportunities to bring into existence 'future; goods and services are discovered, created, and exploited, by whom, and with what consequences" (Cuervo and et al, 2007). The wider relevance of the currently popular opportunity-based conceptualization of entrepreneurship is now attracting increasing research attention. Further, there is growing concern surrounding whether the diversity of wealth creation is being adequately explored. Several lenses need to be applied to explore entrepreneurial actors, events, processes and outcomes relating to the entrepreneur and the profit (and non-profit) organizations they own and/or manage. There is a long history of edited volumes of general readings focusing upon entre-premiership and small business, as well as readings relating to themes such as new firm formation (Cuervo and et al, 2007).

Despite the fact social entrepreneurship has now been a topic of discussion in academic, policy, and practitioner circles for 10 years or more, it was only in 2006 that collections of scholarly papers on the topic began to emerge; then six appeared in the space of six months (in addition to Perrini, see Austin et al., 2006a; Mosher-Williams, 2006; Mair et al., 2006; Nicholls, 2006b; Nyssens, 2006). This sudden outpouring of research contributed to the project of building an academic field of social entrepreneurship in three broad areas: definitional work focused on setting the boundaries of social entrepreneurship; theory development based around conventional disciplinary approaches but with social entrepreneurship/ social enterprise as the unique unit of analysis; new empirical data, especially case studies (Perrini, 2006).

\section{Entrepreneurship as a gate for Social Entrepreneurship}

Any definition of the term "social entrepreneurship" must start with the word "entrepreneurship." The word "social" simply modifies entrepreneurship. If entrepreneurship doesn't have a clear meaning, then modifying it with social won't accomplish much, either.

The word entrepreneurship is a mixed blessing. On the positive side, it connotes a special, innate ability to sense and act on opportunity, combining out-of-the-box thinking with a unique brand of determination to create or bring about something new to the world. On the negative side, entrepreneurship is an ex post term, because entrepreneurial activities require a passage of time before their true impact is evident (Martin \& Osberg, 2007).

Although the concept of social entrepreneurship may be new, initiatives that employ entrepreneurial capacities to solve social problems are not. For years, agencies have launched programs and implemented interventions to help impoverished and marginalized groups. Government aid agencies and private foundations have invested billions of dollars to support such initiatives, and some of them have been quite innovative. But all too often, the results of these initiatives have been disappointing in terms of effectiveness and sustainability, let alone their capacity to scale up their impacts into significant social changes (e.g., Cernea, 1987; Tendlar, 1989).

\section{What is social entrepreneurship?}

Definitions of social entrepreneurship range from broad to narrow. In the former, social entrepreneurship refers to innovative activity with a social objective in either the for-profit sector, such as in social-purpose commercial ventures (e.g., Dees \& Anderson, 2003; Emerson \& Twersky, 1996) or in corporate social entrepreneurship (e.g., Austin, Leonard, Reficco, \& Wei-Skillern, 2004), or in the nonprofit sector, or across sectors, such as hybrid structural forms which mix for-profit and nonprofit approaches (Dees, 1998). Under the narrow definition, social entrepreneurship typically refers to the phenomenon of applying business expertise and market-based skills in the nonprofit sector such as when nonprofit organizations develop innovative approaches to earn income (Reis, 1999; Thompson, 2002). Common across all definitions of social entrepreneurship is the fact that the underlying drive for social entrepreneurship is to create social value, rather than personal and shareholder wealth (e.g., Zadek \& Thake, 1997), and that the activity is characterized by innovation, or the creation of something new rather than simply the replication of existing enterprises or practices. The central driver for social entrepreneurship is the social problem being addressed, and the particular organizational form a social enterprise takes should be a 
decision based on which format would most effectively mobilize the resources needed to address that problem. Thus, social entrepreneurship is not defined by legal form, as it can be pursued through various vehicles. Indeed, examples of social entrepreneurship can be found within or can span the nonprofit, business, or governmental sectors. Also, social entrepreneurship is defined here as the practice of responding to market failures with transformative and financially sustainable innovations aimed at solving social problems. These three essential components:

1. Response to market failures

2. Transformative innovation

3. Financial sustainability - are discussed in more detail below.

1). In addressing market failures, a social entrepreneur might find that there is:

No market - beneficiaries are unable to pay anything and, as a result, costs must be fully subsidized (Example: Resolve to Stop the Violence Program: cited in: Public innovator, 2008).

Limited market - beneficiaries have some ability to pay, and thus the social entrepreneur can rely on some earned revenues to sustain the initiative (Example: ITN America cited in: Public innovator, 2008).

Low-profit market - beneficiaries have the capacity to pay the full cost and the social entrepreneur thus has the potential to generate a profit. However, the market may be underdeveloped or investments in this market may yield returns that are less than typical for for-profit ventures (Example: Beneath).

2). Potentially transformative solutions can be completely new inventions or creative adaptations of existing ones. For entrepreneurs, whether in the business or social realm, innovation is not a one-time event but continues over time (Public innovator, 2008).

3). Financial sustainability is achieved through a combination of:

Nonfinancial resources - the skilled or unskilled volunteers and one-time or recurring in-kind donations that enable social entrepreneurs to increase the sustainability of their initiatives.

Predictable revenue sources includes long-term, repeat, and performance-based funding sources-foundation, individual, government, corporate, and fee-based that will provide predictable funding, despite conditions of market failure (Public innovator, 2008)

\section{Who is social Entrepreneur?}

A social entrepreneur is an individual, group, network, organization, or alliance of organizations that seeks sustainable, large-scale change through pattern-breaking ideas in what and/or how governments, nonprofits, and businesses do to address significant social problems.

This definition contains eight basic assumptions about the sources, goals, and strategies of social entrepreneurs, the socially-entrepreneurial organizations they either build or inherent, or the less-entrepreneurial organizations they change to full-blown socially-entrepreneurial purposes.

1. Social entrepreneurs do not have to be individuals - they can also be small groups or teams of individuals, organizations, networks, or even communities that band together to create pattern-breaking change. This assumption moves the field away from individual-centered study, while expanding the number of potential social entrepreneurs that might already exist (Bryna \& Levin, 1991).

2. Social entrepreneurs seek sustainable, large-scale change. This assumption, which adopts the prevailing goal-oriented nature of the contemporary debate, nonetheless moves the field away from questions about who becomes an entrepreneur to what they seek, while again expanding the number of potential social entrepreneurs that might exist (social entrepreneurship, 2006).

3. Social entrepreneurship can involve pattern-breaking ideas in either how or what gets done to address significant social problems. This assumption moves the field toward a broader definition of social entrepreneurship that includes organizational and administrative reforms, as well as "using old stuff in new ways."* It also embraces Dees definition of "enterprising social innovation" as a blend of the social enterprise (or market-driven) school of thought with the "social innovation" school presented in this volume (social entrepreneurship, 2006).

4. Social entrepreneurs exist in and between all sectors. This assumption opens the discussion beyond nonprofits to include other sectors and multi sectored entities. Social entrepreneurship may be more difficult to launch and sustain in government, for example, where the penalties for risk taking are immediate, but it exists nonetheless. Again, it also embraces Dees and Anderson's notion of "sector-bending" organizations that use elements of 
nonprofit and for-profit thinking (social entrepreneurship, 2006).

5. Social entrepreneurs need not engage in social enterprise or use market-based tools to be successful. This assumption breaks the necessary-but-not-sufficient relationship between social enterprise and social entrepreneurship by rendering earned income as one of many possible means to a social-purpose end. As Dees (2004) recently writes, "Successful social entrepreneurs will use the most effective structures, strategies, and funding mechanisms to achieve their social objectives. Social entrepreneurship should not be seen as a funding strategy, and it should not be tied to the idea of business ventures....At its heart, entrepreneurship is about establishing new and better ways to create value" (p. 17). It is important to note that Dees' more recent work suggests that the use of market-driven tools such a micro-finance may be a way of distinguishing between different types of social innovation (Bryna \& Levin, 1991).

6. The quantity of social entrepreneurship can vary greatly across individuals and entities. Some social entrepreneurs will be very entrepreneurial compared to others, while others may restrict their entrepreneurial activity to a particular program or unit. This assumption allows for comparisons across individuals and entities that are very, fairly, or only somewhat entrepreneurial, which may yield valuable knowledge on the conditions that might permit greater activity, as well as the conditions that might make lower levels of entrepreneurship quite appropriate (Bryna \& Levin, 1991).

7. The intensity of social entrepreneurship can and does ebb and flow over time as circumstances change. This assumption allows further study of the economic, political, social, and organizational conditions that might explain stall points, pauses, stops, and restarts in socially-entrepreneurial activity. Under this assumption, social entrepreneurs can occasionally look very non-entrepreneurial as they consolidate, retrench, or respond to inevitable external pressures. Challenge the conventional wisdom, and the conventional wisdom will almost always challenge back - that is, after all, how the conventional wisdom survives (Public innovator, 2008).

8. Social entrepreneurs sometimes fail, though at as-yet-to-be-determined rates. Much as they may seek to create pattern-breaking change, they face serious barriers to success, not the least of which is the tendency of the status quo to push back against pattern-breaking change. That is, after all, the way the status quo endures (Bryna \& Levin, 1991).

\section{Scope of Social Entrepreneurship}

The social entrepreneurship research arena is hindered by the many terms and definitions adopted by researchers and policy-makers. Social enterprises have been varyingly described as "a private enterprise conducted in the public interest" (OECD 1999:10), a for-profit social venture (Dees and Anderson 2003), and a social purpose enterprise (Wallace 1999). Further, social enterprises adopt differing legal formats and abide by different legal frameworks and fiscal responsibilities and duties in different countries. These factors make national and international comparisons of social enterprise activity unreliable at present. Although universally acceptable definitions of social entrepreneurship, social enterprise and social entrepreneur do not exist (OECD 1999), there appears to be a converging consensus on the meaning of social enterprise, and from this it is possible to draw out a definition of a social entrepreneur and social entrepreneurship (Haugh, 2005,p.2).

\section{How can government strategically support social entrepreneurship?}

While government currently lacks a comprehensive and strategic approach for collaborating with social entrepreneurs, isolated incidents do exist of local, state, and federal employees working with social entrepreneurs through five primary methods. By embracing these methods more strategically, government leaders can help to dramatically move the dial on crucial social issues:

1. Encourage social innovation - For any entrepreneur, the start-up period of an organization is critical. Public innovators can encourage social innovation and help spur the testing of promising new approaches to solving social problems (Public innovator, 2008).

2. Create an enabling environment for social innovation and entrepreneurship - The very nature of innovation means that social entrepreneurs will be heading into new territory, and they often encounter unexpected barriers along the way. Public innovators can lift such barriers for social entrepreneurs. In addition, merely by lending credibility and drawing attention to a given issue or initiatives, they can help social entrepreneurs gather momentum (Public innovator, 2008).

3. Reward social-entrepreneurial initiatives for exceptional performance - Access to reliable sources of funding are essential to the growth and sustainability of solutions that work. . By tying decisions about funding and purchasing to performance, government can help ensure that solutions that work will sustain and grow their impact (Public innovator, 2008). 
4. Scale successful approaches - Expanding the reach of a proven solution is often critical if the solution is to become truly transformative. Yet acquiring the recognition, support for dissemination, or funding to scale a successful initiative is notoriously difficult. Government can play a crucial role in expanding the reach of solutions that work by seeking out what works and enabling solutions to scale (Public innovator, 2008).

5. Produce knowledge - Government already serves as a critical source of data and standards that help entrepreneurs. Public innovators can play a critical role in ensuring that knowledge is produced, more clear standards are set, and data is easily accessible (Public innovator, 2008).

\section{Social Entrepreneurship by using Entrepreneurship Education}

For developing a good and professional social entrepreneurship in a country, government officials and public policy makers should use elements of an effective entrepreneurship education system for educating citizens about the attributes and benefits of quality social entrepreneurship. This section is based on a study of the US-American Consortium of Entrepreneurship Education, which points out five stages to the entrepreneurial spirit.

\section{Objectives of Entrepreneurship Education}

Entrepreneurship education is often seen as a special kind of training to become an entrepreneur or to enlarge job prospects of the individual. With this kind of education, various goals are combined. Based on the Expert Group "Education for Entrepreneurship" of the European Commission and the National Consortium of Entrepreneurship Education U.S.A, this section will show the main arguments promoting entrepreneurship education and point out their main objectives. Due to the main intentions some special problems may occur in practice.

There are two special objectives of entrepreneurship education. In a broader view, entrepreneurial attitudes and skills shall be promoted, in a narrow sense a specific training on how to create a business is provided. The European Expert Group agreed about five objectives of Entrepreneurship Education:

Expert group: Education for Entrepreneurship: Objectives of teaching about entrepreneurship (EGEE 2004: 12)

"Promoting the development of personal qualities that are relevant to entrepreneurship, such as creativity, spirit of initiative, risk-taking and responsibility;

Offering early knowledge of and contact with the world of business, and some understanding of the role of entrepreneurs in the community;

Raising students' awareness of self-employment as a career option (the message being that you can become not only an employee, but also an entrepreneur);

Organising activities based on learning by doing - for example by means of students running mini-companies or virtual firms;

Providing specific training on how to start a business (especially in vocational or technical schools and at university level)."

Similarly the US-American Consortium of Entrepreneurship Education points out five stages to the entrepreneurial spirit.

\begin{tabular}{|l|l|l|}
\hline \multicolumn{2}{|l|}{ Entrepreneurship Education, a Lifelong Learning Process (NCSEE 2004 ... nurturing.htm) } \\
\hline Stage & supposed to & Target group \\
\hline Basics & $\begin{array}{l}\text { understand economics and free enterprise } \\
\text { identify career options } \\
\text { gain prerequisite basic skills }\end{array}$ & $\begin{array}{l}\text { primary grades, } \\
\text { junior high, } \\
\text { high school }\end{array}$ \\
\hline $\begin{array}{l}\text { Competency } \\
\text { awareness }\end{array}$ & $\begin{array}{l}\text { understand problems of employers } \\
\text { discover entrepreneurship competencies }\end{array}$ & career and technical education \\
\hline $\begin{array}{l}\text { Creative } \\
\text { applications }\end{array}$ & $\begin{array}{l}\text { learn how to create new businesses } \\
\text { apply specific occupational training }\end{array}$ & $\begin{array}{l}\text { advanced high school career and technical } \\
\text { programs, Colleges }\end{array}$ \\
\hline
\end{tabular}




\begin{tabular}{|l|l|l|}
\hline & learn entrepreneurship competencies & \\
\hline Start Up & $\begin{array}{l}\text { develop policies and procedures for a new or } \\
\text { existing businesses } \\
\text { become self-employed }\end{array}$ & training programs for adults \\
\hline Growth & $\begin{array}{l}\text { solve business problems effectively } \\
\text { expand existing businesses }\end{array}$ & programs to assistant entrepreneurs \\
\hline
\end{tabular}

Finally the US-National Consortium develops 403 content standards, grouped to 15 major standards, again to three sections of entrepreneurial skills, ready skills and business function.

\begin{tabular}{|l|l|l|}
\hline \multicolumn{2}{|l|}{ Major Standards of entrepreneurship education (NCSEE 2004... standards_detail.htm) } \\
\hline Entrepreneurial Skills & Ready Skills & Business Functions \\
\hline - Entrepreneurial & - Business Foundations: Business concepts and & - Financial \\
$\begin{array}{l}\text { Processes: discovery, } \\
\text { concept development, } \\
\text { resourcing, Actualization, }\end{array}$ & - Cusiness activities & Management \\
Harvesting & - Digital skills & Human Resource \\
Entrepreneurial Traits / & - Economics: Basic Concepts, Cost-Profit & Management \\
Behaviour: Leadership, & Relationships, Economic Indicators / Trends, & Management \\
Personal Assessment and & Economic Systems, International Concepts & - Marketing \\
Management & - Financial Literacy: Money Basics, Financial & Management \\
& Services, Personal Money Management & - Operations \\
& Professional Development: Career Planning, & Management \\
& Job-Seeking Skills & - Risk Management \\
& & - Strategic \\
\end{tabular}

The content standards have to be understood as a kind of comprehensive tool box including business and economic knowledge as well as personal and ethical competences. However, they are not targeted to specific grade levels.

\section{Conclusion}

Entrepreneurship, or entrepreneurial activity with an embedded social purpose, has been on the rise in recent decades. A partial indicator of this surge is revealed by the growth in the number of nonprofit organizations, which increased 31\% between 1987 and 1997 to 1.2 million, exceeding the $26 \%$ rate of new business formation (The New Nonprofit Almanac and Desk Reference, 2002). However, the dynamic is even more robust, as other forms of social entrepreneurship, beyond that occurring within the nonprofit sector, have also flourished in recent years (Austin, 2006). The recent boom in social entrepreneurial activity makes a comparative analysis between commercial and social entrepreneurship timely. Social entrepreneurship is still emerging as an area for academic inquiry. Its theoretical underpinnings have not been adequately explored, and the need for contributions to theory and practice are pressing (Austin, 2006).

Social Entrepreneurship by itself shows up frequently in the media, is referenced by public officials, has become a common topic of discussion on university campuses, and informs the strategy of several prominent social sector organizations. The reasons behind the popularity of social entrepreneurship are many. On the most basic level, there's something inherently interesting and appealing about entrepreneurs and the stories of why and how they do what they do. As well, government officials and policy makers should try to expand social entrepreneurship talents in the society for expanding economic conditions and the quality of life.

\section{References}

Alvord, Sarah H., L. David Brown and Christine W. Letts. (2004). Social Entrepreneurship and Societal Transformation: An Exploratory Study. Journal of Applied Behavioral Science, 40, 260.

Austin, James, Howard Stevenson \& Jane Wei-Skillern. (2006). Social and Commercial Entrepreneurship: Same, 
Different, or Both?, ENTREPRENEURSHIP THEORY and PRACTICE, January.

Austin, J., Gutierrez, R., Ogliastri, E. and Reficco, R. (eds) (2006a). Effective Management of Social Enterprises. Cambridge, MA: David Rockefeller Center Series on Latin American Studies, Harvard University.

Austin, J.E., Leonard, H., Reficco, E., \& Wei-Skillern, J. (2004). Corporate social entrepreneurship: A new vision of CSR. Harvard Business School Working Paper No. 05-021. Boston: Harvard Business School.

Brown, L. D., \& Covey, J. G. (1987). Development organizations and organization development: Implications for a new paradigm. InW. Pasmore \& R.Woodman (Eds.), Research in organization change and development (Vol. 1, pp. 59-88). Greenwich, CT: JAI.

Bryna, Mary Sanger, and Martin Levin. (1991). Using Old Stuff in New Ways: Innovation as a Case of Evolutionary Tinkering. Journal of Policy Analysis and Management, Vol. 10, No. 4, Fall.

Cernea, M. (1987). Farmer organizations and institution building for sustainable agricultural development. Regional Development Dialogue, 8(2), 1-24.

Cuervo lvaro, Domingo Ribeiro and Salvador Roig. (2007). Entrepreneurship: Concepts, Theory and Perspectives. Berlin: Springer Verlag and Heidelberg, 2007. 348 pp. ISBN 978-354048-542-2, £69.

Dees J. G. and Anderson B. B. (2003). For-Profit Social Ventures. In Social entrepreneurship, Eds. M. L. Kourilsky and W. B. Walstad. Birmingham, UK: Senate Hall Academic Publishing.

Dees, J. G. (1998, January/February). Enterprising nonprofits: What do you do when traditional sources of funding fall short? Harvard Business Review, pp. 55-67.

Dees, J.G. \& Anderson, B.B. (2003). For-profit social ventures, International Journal of Entrepreneurship Education (special issue on social entrepreneurship), 2, 1-26.

Dees, J.G. (1998). The meaning of "social entrepreneurship." Comments and suggestions contributed from the Social Entrepreneurship Founders Working Group. Durham, NC: Center for the Advancement of Social Entrepreneurship, Fuqua School of Business, Duke University. [Online] Available: http://faculty.fuqua.duke.edu/centers/case/files/dees-SE.pdf.

EGEE 2004: Final Report of the Expert Group "Education for Entrepreneurship": Making Progress in promoting entrepreneurial attitudes and skills through Primary and Secondary education. Brussels February 2004. [Online] Available:http://europa.eu.int/comm/enterprise/entrepreneurship/support_measures/training_education/final_repo rt_february.pdf.

Emerson, J. \& Twerksy, F. (Eds.). (1996, September). New social entrepreneurs: The success, challenge and lessons of non-profit enterprise creation. San Francisco: Roberts Foundation, Homeless Economic Development Fund.

Emerson, J. \& Twersky, F. (Eds). (1996, September). New social entrepreneurs: The success, challenge and lessons of non-profit enterprise creation. San Francisco: Roberts Foundation, Homeless Economic Development Fund.

F. Perrini. (2006). The New Social Entrepreneurship: What Awaits Elgar, 2006. 341 pp. ISBN: 1845427815.

Haugh, Helen. (2005). A research agenda for social entrepreneurship. Social Enterprise Journal, Volume Number 1, Issue 1. March 2005, pp.1-13.

Haugh, Helen. (2007). NEW STRATEGIES FOR A SUSTAINABLE SOCIETY: THE GROWING CONTRIBUTION OE SOCIAL Entrepreneurship, Business Ethics Quarterly, Volume 17, Issue 4. ISSN 1052-150X. pp. 743-749.

Korten, D. C. (1980). Rural organization and rural development: A learning process approach. Public Administration Review, 40, 480-511.

Krishna, A., Uphoff, N., \& Esman, M. J. (Eds.). (1997). Reasons for hope: Instructive experiences in rural development. West Hartford, CT: Kumarian.

Mair, J., Robinson, J. and Hockrts, K. (2006). Social Entrepreneurship. Basingstoke: Palgrave Macmillan.

Martin, ROGER L. \& SALLY OSBERG. (2007). Social Entrepreneurship the case for definition, spring 2007/ STANFORD SOCIAL INNOVATION REVIEW 29-39. [Online] Available: www.ssireview.org.

Mosher-Williams, R. (ed.) (2006). 'Research on Social Entrepreneurship: Understanding and Contributing to an Emerging Field', Occasional Papers Series No. 1.3, ARNOVA. 
NCSEE 2004: Consortium for Entrepreneurship Education: National Content Standards for Entrepreneurship Education. [Online] Available: http://www.entre-ed.org/Standards_Toolkit/.

Nicholls, A. (ed.) (2006b). Social Entrepreneurship: New Models of Sustainable Social Change. Oxford: Oxford University Press.

Nyssens, M. (ed.) (2006). Social Enterprise. London: Routledge.

OECD. (1999). Social Enterprises. Paris: OECD.

Paul, S. (1982). Managing development programs: The lessons of success. Boulder, CO: West view.

Public Innovator. (2008). Connecting government with entrepreneurial solutions to today's toughest problems. [Online] Available: http://www.publicinnovators.com/what-social-entrepreneurship.

Reis, T. (1999). unleashing the new resources and entrepreneurship for the common good: A scan, synthesis and scenario for action. Battle Creek, MI: W.K. Kellogg Foundation.

Social Entrepreneurship. (2006). Finding social entrepreneurs. [Online] Available: http://www.socialedge.org/blogs/let-there-be-light/topics/Social\%20Entrepreneurship.

Tendlar, J. (1989). Whatever happened to poverty alleviation? New York: Ford Foundation.

Thake, S., \& Zadek, S. (1997). Practical people, noble causes: How to support community-based social entrepreneurs. London: New Economics Foundation.

The new nonprofit almanac \& desk reference. (2002). San Francisco: Jossey-Bass.

Wallace S. L. (1999). Social Entrepreneurship: The role of social purpose enterprises in facilitating community economic development, Journal of Developmental Entrepreneurship, 4, 2, pp.153-174.

Zadek, S. \& Thake, S. (1997, June 20). Send in the social entrepreneurs. New Statesman, 26, 31. 